\title{
Antibacterial Xanthones from Kielmeyera variabilis Mart. (Clusiaceae)
}

\author{
Lucimar Pinheiro, Celso Vataru Nakamura*, Benedito Prado Dias Filho*, \\ Antonio Gilberto Ferreira**, Maria Claudia Marx Young***, \\ Diógenes Aparicio Garcia Cortez/ ${ }^{+}$
}

\begin{abstract}
Departamento de Farmácia e Farmacologia *Departamento de Análises Clínicas, Universidade Estadual de Maringá, Av. Colombo 5790, 87020-900 Maringá, PR, Brasil **Departamento de Química, Universidade Federal de São Carlos, São Carlos, SP, Brasil

***Instituto de Botânica de São Paulo, São Paulo, SP, Brasil
\end{abstract}

The bioassay-guided fractionation of stems from Kielmeyera variabilis, traditionally used in Brazilian folk medicine, yielded assiguxanthone-B (1), kielcorin (4), 2,5-dihydroxybenzoic acid (3), and a mixture of xanthones containing assiguxanthone- $B$ (1) and 1,3,5,6-tetrahydroxy-2-prenylxanthone (2) (1:1 w/w). The xanthone mixture inhibited Staphylococcus aureus and Bacillus subtilis at a concentration of $6.25 \mu \mathrm{g} / \mathrm{ml}$. When tested alone, the minimal inhibitory concentration of assiguxanthone-B was $25 \mu \mathrm{g} / \mathrm{ml}$ against B. subtilis. Kielcorin and 2,5dihydroxybenzoic acid were inactive against both strains. None of the fractions was active against Escherichia coli or Pseudomonas aeruginosa. Viable cells of S. aureus were reduced by a 1-3 log CFU/ml within $12 \mathrm{~h}$ after exposure of one to eight times the MIC of the xanthone mixture. It is not known whether the tetrahydroxy-2-prenylxanthone or other components of the xanthone mixture are responsible for the main antibacterial activity or whether additive or synergistic action is involved

Key words: Kielmeyera variabilis - Clusiaceae - xanthones - antibacterial activity

Kielmeyera variabilis Mart. (Clusiaceae), a tree commonly known in Brazil as "malva-do-campo" (Syn. "pausanto"), is traditionally used in Brazilian folk medicine to treat several tropical diseases including schistosomiasis, leishmaniasis, malaria, fungal and bacterial infections (Alves et al. 2000). A previous phytochemical investigation of the genus Kielmeyera reported activity of xanthones and biphenyl derivatives against Cladosporium cucumerinum and Candida albicans isolated from leaves and stems of $K$. coriacea (Cortez et al. 1998, 1999). No other literature reports were found on the chemical constituents of $K$. variabilis.

Iinuma et al. (1996) have reported on the antibacterial activity of xanthones from the family Guttifereae against methicillin-resistant Staphylococcus aureus (MRSA). According to these authors, one active isolate, alphamangostin, a xanthone derivative had antibacterial activity. These authors reported that rubraxanthone, which is isolated from Garcinia dioica and has a structure similar to that of alpha-mangostin, had the greatest activity against staphylococcal strains.

Supported by grants from the Conselho Nacional de Desenvolvimento Científico e Tecnológico-CNPq, Capacitação de Aperfeiçoamento de Pessoal de Nível Superior-Capes, and Programa de Pós-graduação em Ciências Farmacêuticas, Universidade Estadual de Maringá.

${ }^{+}$Corresponding author. Fax +55-44-263.6231. E-mail: dagcortez@uem.br

Received 3 October 2002

Accepted 7 March 2003
The use and search for drugs and dietary supplements derived from plants have accelerated in recent years (Cowan 1999). Ethnopharmacologists, botanists, microbiologists, and natural-products chemists are combing the Earth for phytochemicals and "leads" which could be developed for treatment of infectious diseases. According to Cowan (1999), while 25 to $50 \%$ of current pharmaceuticals are derived from structures found in plants, very few are intended for use as antimicrobials.

Prompted by these reports, the present study was undertaken to investigate the in vitro antibacterial activity of the separated fractions of methanolic extracts from the stems of $K$. variabilis. We are reporting our results of the antibacterial activity of xanthones, isolated by bioassay-guided fractionation of the methanolic extract of the stems of $K$. variabilis. Time-kill studies were also performed to determine if xanthones had bactericidal activity.

\section{MATERIALS AND METHODS}

Instruments $-{ }^{1} \mathrm{H}$ and ${ }^{13} \mathrm{C}$ nuclear magnetic resonance were performed on a Gemini 300 and a Bruker 400 NMR spectrometers (Varian, USA and Bruker, Germany respectively). Mass spectra were determined by VG Platform II and CG/EM - Shimadzu QP 2000 spectrometer (Micromass, USA and Shimadzu, Japan respectively).

Plant collection - Stems of $K$. variabilis were collected in Moji-Guaçu, São Paulo, Brazil, in April 1999 and a voucher (no. SP 346929) was deposited at the herbarium of the Instituto Botânico de São Paulo.

Plant extract and fractionation - The powdered stems $(500 \mathrm{~g})$ of $K$. variabilis were successively extracted at room temperature with hexane and methanol to give, after evaporation of the solvents and liophylization, $30 \mathrm{~g}$ of hexane extract and $34 \mathrm{~g}$ of methanol extract. The methanol 
and hexane extracts were screened for antimicrobial activity as described below. The methanol active extract was subjected to fractionation by vacuum chromatography on an Avicel ${ }^{\circledR}$ column and eluted with n-hexane, $\mathrm{CH}_{2} \mathrm{Cl}_{2}$, $\mathrm{CH}_{2} \mathrm{Cl}_{2}$-EtOAc (1:1), EtOAc, $\mathrm{MeOH}$ and (1:1), EtOAc, and $\mathrm{MeOH}$ to afford the fractions F1 (0.6 g), F2 (2.7 g), F3 (0.5 g), F4 (0.2 g), F5 (1 g), and F6 (0.4 g). The more active fractions, F3 and F4, were combined and submitted to gel chromatography on Sephadex LH-20 column chromatography using $\mathrm{CHCl}_{3}-\mathrm{MeOH}(1: 1)$ as eluent to give 40 fractions. Fractions 16 to 18 were combined and rechromatographed on Sephadex LH-20 and on silica gel 60 (230$400 \mathrm{mesh})(250 \mathrm{~g})$ column chromatography eluted with hexane, hexane-EtOAc and EtOAc yielding $2.2 \mathrm{~g}$ of a mixture of xanthones (compound 1 and 2). Fractions 19 to 21 were combined and rechromatographed on Sephadex LH20 column chromatography eluted with $\mathrm{MeOH}, \mathrm{EtOAc}$ and $\mathrm{MeOH}$ affording $4.6 \mathrm{mg}$ of xanthone (compound 1) and $2.5 \mathrm{mg}$ of organic acid (compound 3 ). The active fractions F5 and F6 were combined and chromatographed on Sephadex LH-20 column chromatography using $\mathrm{MeOH}$, MeOH: $\mathrm{H}_{2} \mathrm{O}$ (9:1) and $\mathrm{MeOH}: \mathrm{H}_{2} \mathrm{O}$ : EtOAc (45:5:1) as eluents to give 67 fractions. Fraction $10(245 \mathrm{mg})$ was rechromatographed on Sephadex LH-20 yielding the active fraction $6(53 \mathrm{mg})$, which was purified by preparative thin-layer chromatography (TLC) (silica gel $\mathrm{GF}_{254}$, Hexane: $\mathrm{CH}_{2} \mathrm{Cl}_{2}: \mathrm{MeOH}, 5: 4: 1$ ), affording $2.1 \mathrm{mg}$ of xanthone (compound 4). Compounds 1, 2, 3, and 4 (Fig. 1) were identified as assiguxanthone-B (Chihiro et al. 1997), 1,3,5,6tetrahtydroxy-2-prenylxanthone (Goh et al. 1991), benzoic acid 2,5-dihydroxy (Bankova et al. 1987) and kielcorin (Pinto et al. 1987), respectively, by spectroscopic analysis and by comparison with literature data<smiles>CC(C)=CCc1c(O)cc2oc3cc(O)c(O)cc3c(=O)c2c1O</smiles>

1<smiles>O=C(O)c1cc(O)ccc1O</smiles>

3<smiles></smiles>

Fig. 1: compounds 1 (assiguxanthone-B), 2 (1,3,5,6-tetrahydroxy2-prenylxanthone), 3 (2,5-dihydroxybenzoic acid), 4 (kielcorin) from Kielmeyera variabilis and 5 (calozeyloxanthone) from Calophyllum moonii.
Microorganisms used and growth conditions - The following microorganisms were used for detecting antibacterial activity: Escherichia coli ATCC 25922, Pseudomonas aeruginosa ATCC 15442, Bacillus subtilis ATCC 6623 and S. aureus ATCC 25923. Cultures of these bacteria were grown in nutrient broth (Difco) at $37^{\circ} \mathrm{C}$ and maintained on nutrient agar slants at $4^{\circ} \mathrm{C}$.

Antimicrobial susceptibility testing - The minimum inhibitory concentrations (MICs) of all compounds and reference antibiotics were determined by microdilution techniques in Mueller-Hinton broth (Merck S.A., São Paulo, Brazil) as described by the National Committee for Clinical Laboratory Standards (2000). Each inoculum was prepared in the same medium at a density adjusted to a 0.5 McFarland turbidity standard $\left[10^{8}\right.$ colony-forming units $(\mathrm{CFU}) / \mathrm{ml}$ ] and diluted 1:100 for the broth microdilution procedure. Microtiter trays were incubated at $37^{\circ} \mathrm{C}$ and the MICs were recorded after $24 \mathrm{~h}$ of incubation. Two susceptibility endpoints were recorded for each isolate. The endpoint MIC is the lowest concentration of a compound at which the microorganism tested does not demonstrate visible growth. Minimum bactericidal concentrations (MBCs) were defined as the lowest concentration yielding negative subcultures or only one colony.

Time-kill curve methodology - Prior to experimentation, the lower limit of bacterial quantification and the potential of compound carryover during the plating process were determined as previously described by the $\mathrm{Na}$ tional Committee for Clinical Laboratory Standards (1999). According to these sampling procedures antibacterial carryover was not observed. Additionally, the lower limit of bacterial quantification was $100 \mathrm{CFU} / \mathrm{ml}$. The effects of the xanthone mixture on the growth of $S$. aureus were determined by preparing a standardized suspension as described above. Dilutions yielded a starting inoculum of approximately $1 \times 10^{6}$. The antibacterial activity of xanthone mixture was studied over a range of multiples of MIC encompassing 1 to $8 \mathrm{X}$ MIC. Tests were performed in triplicate with incubation at $37^{\circ} \mathrm{C}$. At predetermined time points $(0,2,4,6,8,10,12 \mathrm{~h})$ a $100 \mu 1$ sample was removed from each test solution, serially diluted in sterile water, and plated on Mueller-Hinton agar plates for colony count determination. Plates were incubated at $37^{\circ} \mathrm{C}$ for $24 \mathrm{~h}$ before colony count determination. Data from triplicate runs were averaged and plotted as $\log \mathrm{CFU} / \mathrm{ml}$ versus time (hours) for each time point.

\section{RESULTS AND DISCUSSION}

Screening tests of hexane and methanol extracts against $S$. aureus, E. coli, B. subtilis, and $P$. aeruginosa by using the microbroth MIC procedure are given in Table I. The results obtained with the methanol extract were more homogeneous, and both $S$. aureus and B. subtilis were considered susceptible with MICs of $3.9 \mu \mathrm{g} / \mathrm{ml}$ and $1.95 \mu \mathrm{g} / \mathrm{ml}$, respectively. E. coli and P. aeruginosa with MIC $>100 \mu \mathrm{g} / \mathrm{ml}$ were considered resistant.

As a result of this finding, the methanol active extract was fractionated on silica gel column chromatography in a bioassay-guided fractionation. Table II summarizes the MICs and Minimum Bactericidal Concentrations (MBCs) of isolated compounds and the xanthone mixture. The xan- 
TABLE I

Minimum inhibitory concentration (MIC) and minimum bactericidal concentration (MBC) of hexane and methanol extracts from the stems of Kielmeyera variabilis

\begin{tabular}{lcc}
\hline & \multicolumn{2}{c}{ MIC $(\mathrm{MBC})(\mu \mathrm{g} / \mathrm{ml})$} \\
\cline { 2 - 3 } Organism & Hexane extract & Methanol extract \\
\hline Staphylococcus aureus & $62.5(125)$ & $3.0(>100)$ \\
Bacillus subtilis & $31.2(62.5)$ & $1.95(62.5)$ \\
Escherichia coli & $>100$ & $>100$ \\
Pseudomonas aeruginosa & $>100$ & $>100$ \\
\hline
\end{tabular}

thone mixture inhibited $S$. aureus and B. subtilis at a concentration of $6.25 \mu \mathrm{g} / \mathrm{ml}$. Assiguxanthone-B alone displayed some activity (MIC $25 \mu \mathrm{g} / \mathrm{ml}$ ) against B. subtilis. 2,5-dihydroxybenzoic acid and kielcorin were inactive against all four strains tested. Under the conditions employed here, the plant compounds demonstrated no activity against $E$. coli and $P$. aeruginosa $(\mathrm{MIC}>100 \mu \mathrm{g} / \mathrm{ml}$ ). The MICs of the reference drugs used in this study were similar to those presented in other reports.

As a result of this finding, a time-kill assay was performed against $S$. aureus with the xanthone mixture to determine if this mixture had bactericidal activity. As shown in Fig. 2, viable cells of $S$. aureus were reduced by $3 \log _{10} \mathrm{CFU} / \mathrm{ml}$ within $12 \mathrm{~h}$ after exposure to 8 times the MIC of xanthone mixture. Control (no-drug) exhibited a 3$\log _{10}$ increase in CFU/ml by $4 \mathrm{~h}$. Bacterial culture were monitored for up to $24 \mathrm{~h}$, and no regrowth was observed.

Previously Cortez et al. (1998) reported the presence of several xanthones from dichloromethane extracts of $K$. coriacea. Phytochemical investigation of these extracts resulted in the isolation and identification of ten xanthones, one biphenyl, and two triterpenes. Four xanthones and the biphenyl exhibited antifungal activity against the plant pathogenic fungus Cladosporium cucumerinum, while two prenylated xanthones inhibited the growth of Candida albicans. Recently, Dharmaratne et al. (1999) studied the antimicrobial activity of Calophyllum xanthone with a special reference to methicillin-resistant $S$. aureus. Calozeyloxanthone, a xanthone which has been isolated from C. moonii and C. lankensis, showed the greatest activity against methicillin-resistant $S$. aureus strains with a MIC of $8.3 \mu \mathrm{g} / \mathrm{ml}$.
As described above, bioassay-guided fractionation of methanolic extracts of the dry stems from $K$. variabilis permitted the isolation of assiguxanthone-B (1) and 1,3,5,6-tetrahydroxy-2-prenylxanthone (4). But under the conditions employed other active constituents of the xanthone mixture were not separated. Isolated assiguxanthone-B showed only moderate antibacterial activity (MIC $25 \mu \mathrm{g} / \mathrm{ml}$ ) against B. subtilis in contrast with the methanol extract with MIC of $1.95 \mu \mathrm{g} / \mathrm{ml}$. Whether the main antibacterial activity is due to 1,3,5,6-tetrahydroxy2-prenylxanthone or the other components or whether activity is due to additive or synergistic action has not yet been determined. As discussed by Briskin (1999), in contrast to the synthetic pharmaceuticals based upon single chemicals, many phytomedicines exert their beneficial effects through additive or synergistic actions of several compounds acting at single or multiple target sites associated with a physiological process.

Finally, the results showed that the plant could be explored for possible antimicrobial agents and support its use for the treatment of wounds, which are contaminated with bacterial organisms.

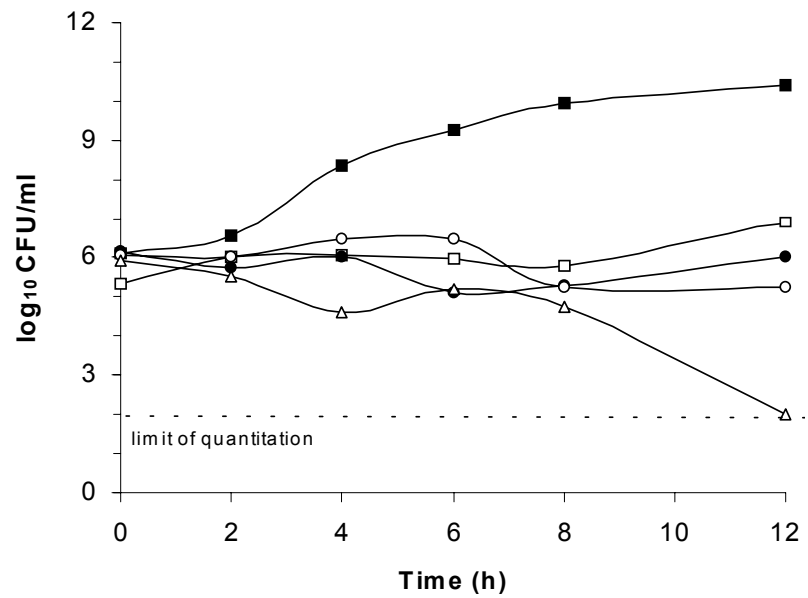

Fig. 2: representative time-kill curve plot of xanthone mixture (compounds 1 and 2) against Staphylococcus aureus at the following concentrations: $\quad \mathbf{\square}$, control (no drug); $\square, 6.25 \mu \mathrm{g} / \mathrm{ml}$ (MIC); $\bullet$, $12.5 \mu \mathrm{g} / \mathrm{ml}$ (2x MIC); O, $25.0 \mu \mathrm{g} / \mathrm{ml}$ (4x MIC); $\Delta, 50.0 \mu \mathrm{g} / \mathrm{ml}(8 \mathrm{x}$ MIC)

TABLE II

Minimum inhibitory concentration (MIC) and minimum bactericidal concentration (MBC) of assiguxanthone-B, 2,5-dihydroxy benzoic acid, Kielcorin and assiguxanthone-B and 1,3,5,6-tetrahtydroxy-2-prenylxanthone mixture from Kielmeyera variabilis

$\mathrm{MIC}(\mathrm{MBC})(\mu \mathrm{g} / \mathrm{ml})$

\begin{tabular}{lcccr} 
Organism & Assiguxanthone & $\begin{array}{c}2,5 \text {-dihydroxybenzoic } \\
\text { acid }\end{array}$ & Kielcorin & $\begin{array}{r}1,3,5,6 \text {-tetrahydroxy-2- } \\
\text { prenylxanthone mixture }\end{array}$ \\
\hline Staphylococcus aureus & $100(100)$ & $>100$ & $>100$ & $6.25(100)$ \\
Bacillus subtilis & $25(>100)$ & $>100$ & $>100$ & $6.25(25)$ \\
Escherichia coli & $>100$ & $>100$ & $>100$ & $>100$ \\
Pseudomonas aeruginosa & $>100$ & $>100$ & $>100$ & $>100$ \\
\hline
\end{tabular}




\section{ACKNOWLEDGMENTS}

To Marinete Martinez for her technical assistance.

\section{REFERENCES}

Alves TMA, Silva AF, Brandão M, Grandi TSM, Smânia EF, Smânia Jr A, Zani CL 2000. Biological screening of Brazilian medicinal plants. Mem Inst Oswaldo Cruz 95: 367-373.

Bankova V, Dyulgerov A, Popov S, Marekov NZA 1987. GC ms study of the propolis phenolic constituents. Naturforsch C 42: 147-151.

Briskin DP 2000. Medicinal plants and phytomedicines. Linking plant biochemistry and physiology to human health. Plant Physiol 124: 507-554.

Chihiro I, Miyamoto Y, Nakayama M, Kawai Y, Rao KS, Furukawa HA 1997. Novel depsidone and some new xanthones from Garcinia species. Chem Pharm Bull 45: 14031413.

Cortez DAG, Marston A, Hostettmann K 1999. Separation of xanthones and a biphenyl from Kielmeyera coriacea centrifugal partition chromatography. Chromatographia 50: $7-10$.

Cortez DAG, Young MCM, Marston A, Wolfender JL,
Hostettmann K 1998. Xanthones, triterpenes and a biphenil from Kielmeyera coriacea. Phytochemistry 47: 1367-1374.

Cowan MM 1999. Plant products as antimicrobial agents. Clin Microbiol Rev 12: 564-582.

Dharmarantne HR, Wijesinghe WM, Thevanasem V 1999. Antimicrobial activity of xanthones from Calophyllum species, against methicilin-resistant Staphylococcus aureus. J Ethnopharmacol 66: 339-342.

Goh SH, Jantan I 1991. A xanthone from Calophyllum inophyllum. Phytochemistry 30: 366-367.

Iinuma M, Tosa H, Tanaka T, Asai FF, Kobayashi Y, Shimano R, Miyauchi K 1996. Antibacterial activity of xanthones from guttiferaeous plants against methicillin-resistant Staphyloococcus aureus. J Pharm Pharmacol 48: 861-865.

National Committee for Clinical Laboratory Standards 1999. Methods for Determining Bactericidal Activity of Antimicrobial Agents, Approved guideline (M26-A), Wayne, Pa.

National Committee for Clinical Laboratory Standards 2000. Methods for Dilution Antimicrobial Susceptibility Tests for Bacteria that Grow Aerobically, 5th ed. Approved standard (M7-5), Wayne, PA.

Pinto MMM, Mesquita AAL, Gottlieb OR 1987. Xanthonolignoides from Kielmeyera coriacea. Phytochemistry 26: 2045-2048. 